\title{
Structural definition for a new modality of broad and potent antibody neutralization at the CD4-binding site on HIV-1 gp120
}

\author{
T Zhou*, S Moquin, R Lynch, X Wu, J Zhu, Y Yang, B Zhang, JR Mascola, PD Kwong \\ From AIDS Vaccine 2012 \\ Boston, MA, USA. 9-12 September 2012
}

\section{Background}

The initial site of CD4-attachment on HIV-1 gp120 is vulnerable to neutralizing antibodies, and a number of such antibodies have been found that target this site. One set of antibodies, represented by VRC01, mimic $\mathrm{CD} 4$ in their recognition and utilize a common V-gene origin (VH1-2*02). Another set of antibodies, represented by the recently identified VRC13, derives from VH1-69*01 and is able to neutralize over $90 \%$ of circulating HIV-1 isolates, including isolates resistant to VRC01. Do the VRC13-like antibodies also mimic CD4, or do they represent a new modality of effective CD4binding-site neutralization?

\section{Methods}

To define the mode of recognition used by VRC13, we crystallized its antigen-binding fragment in complex with HIV-1 gp120, from both VRC01-sensitive and VRC01resistant strains, and determined these X-ray structures.

\section{Conclusion}

Broad and potent neutralization at the CD4-binding site is not limited to the VRC01-mode of CD4 mimicry. A new mode of effective HIV-1 neutralization, which is defined by the VRC13-gp120 structure and utilizes CDR H3 recognition, may serve as an additional template for the design of an effective HIV-1 vaccine. The natural diversity of the CDR H3 - a product of V-D-J recombination may provide advantages in the elicitation of VRC13-like antibodies.

Published: 13 September 2012

doi:10.1186/1742-4690-9-S2-P57

Cite this article as: Zhou et al:: Structural definition for a new modality of broad and potent antibody neutralization at the CD4-binding site on HIV-1 gp120. Retrovirology 2012 9(Suppl 2):P57.

\section{Results}

The structure of VRC13 indicates a mode of recognition rotated by 45 degrees and translated $\sim 10 \AA$ from that of VRC01, although both VRC01 and VRC13 utilize similar angles of approach. Unlike VRC01-like antibodies, which feature gp120 contacts primarily in the heavy chain 2nd complementarity determining region (CDR H2), VRC13 utilizes a long heavy chain CDR H3 to contact the CD4binding site. Overall, the structural details of VRC13 do not mimic those of CD4.

National Institute of Allergy and Infectious Diseases/NIH, Bethesda, MD, USA

Submit your next manuscript to BioMed Central and take full advantage of:

- Convenient online submission

- Thorough peer review

- No space constraints or color figure charges

- Immediate publication on acceptance

- Inclusion in PubMed, CAS, Scopus and Google Scholar

- Research which is freely available for redistribution 